DOI https://doi.org/10.18551/rjoas.2018-02.15

\title{
ANALYSIS OF SUPPLY CHAIN NETWORKING MUNTOK WHITE PEPPER IN THE PROVINCE OF BANGKA BELITUNG ISLANDS
}

\author{
Agustina Fournita*, Yulia, Astuti Rufti Puji \\ Department of Agribusiness, Faculty of Agriculture Fisheries and Biology, \\ University of Bangka Belitung, Indonesia \\ *E-mail: fournitaagustina@gmail.com
}

\begin{abstract}
This study aims to describe and analyze the supply chain of muntok white pepper in the province of Bangka Belitung Islands. Site selection is done purposively with consideration that South Bangka Regency is the center of production and main supplier of white pepper. The results show that there are three channels of pepper marketing: channel I - farmers sell to village-level collectors, then to district-level collectors, then the district traders sell to exporters; channel II - farmers sell to district-level collector merchants from subsequent districts directly to exporters; channel III - farmers sell directly to exporters. Farmer's share value obtained by farmers is $66.7 \%$.
\end{abstract}

\section{KEY WORDS}

Supply chain, muntok white pepper, margin, farmer's share.

Bangka Belitung Islands Province is the largest white pepper producing center in Indonesia known as Muntok White Pepper. High international market demand and excellence of Muntok White Pepper taste, is an opportunity that must be managed and optimized, so that these opportunities can be optimally utilized. This has made the price of white pepper Bangka Belitung better when compared with the price of other pepper. The development of white pepper prices of Bangka Belitung and Vietnam in general still indicates price fluctuations during June to November 2015. The development of white pepper prices of Bangka Belitung, compared to the price of white pepper Vietnam in 2015 tend to both decrease, as shown in Figure 1.

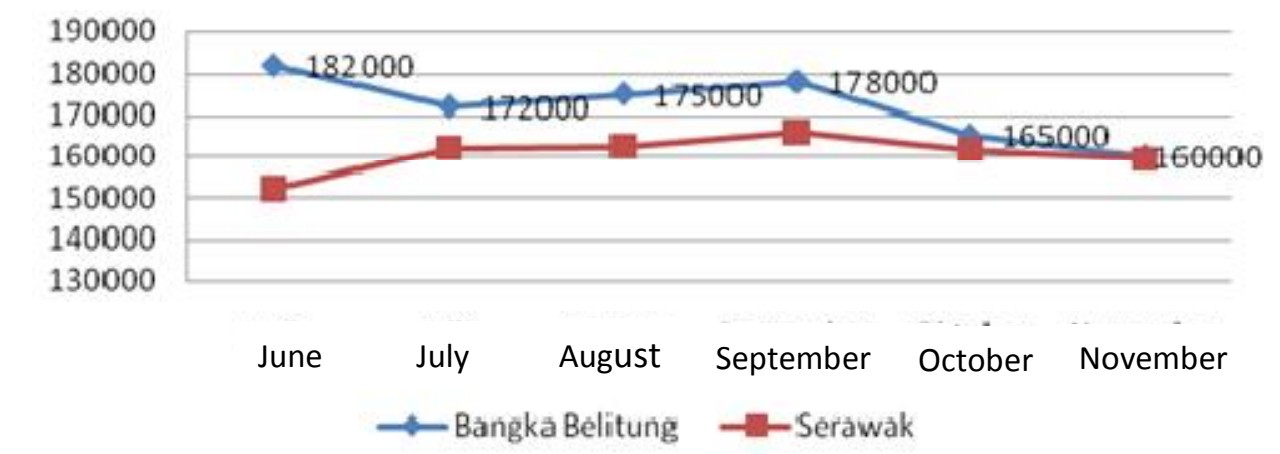

Figure 1 - White Pepper Price Trend June-November 2015 (Source: Association of Exporters of Indonesian Pepper Bangka Belitung, 2015)

White pepper in the province of Bangka Belitung Islands is produced in several districts/cities. The development of white pepper production per Regency/City in Bangka Belitung Islands Province is presented in Table 1

Table 1. shows that the largest white pepper producing district in the province of Bangka Belitung Islands, South Bangka Regency. The development of pepper production in 2010-2015 tended to fluctuate, and showed a decline in production in 2015. This is because the white pepper exploitation of Bangka Belitung is still faced with an interesting problem, especially in terms of marketing. This is certainly detrimental to the company, because the problem of inventory stability determines the quality of service, capital, and cost of the 
company. This condition has significantly impacted the decline in the number of export companies in Bangka Belitung, leaving only 4 active export companies operating until 2016.

Table 1 - The Development of Pepper Production in the Regency / City of Bangka Belitung Islands Province in 2010-2015

\begin{tabular}{|c|c|c|c|c|c|c|}
\hline \multirow{2}{*}{ Regency / City } & \multicolumn{7}{|c|}{ Papper Production (Ton) } \\
\cline { 2 - 7 } & 2010 & 2011 & 2012 & 2013 & 2014 & 2015 \\
\hline Bangka & 3425 & 3400 & 2813 & 2965 & 3189 & 3359 \\
\hline Belitung & 4027 & 7241 & 5255 & 5124 & 5341 & 4213 \\
\hline West Bangka & 1876 & 1943 & 6167 & 4644 & 4345 & 4413 \\
\hline Central Bangka & 637 & 724 & 916 & 1159 & 1686 & 1900 \\
\hline South Bangka & 8168 & 12938 & 16789 & 17112 & 17227 & 15711 \\
\hline East Belitung & 340 & 1996 & 2441 & 2593 & 2040 & 1812 \\
\hline Pangkalpinang & - & - & - & - & - & - \\
\hline Amount & 18472 & 28242 & 34379 & 33596 & 33828 & 31408 \\
\hline
\end{tabular}

Source: Agriculture, Plantation and Livestock Service Office of Bangka Belitung Islands Province (2016).

This problem also directly affects the farmers as producers, especially in determining the selling price of pepper at the farm level. Therefore, the study of mapping of supply chain system of pepper in Bangka Belitung is important to do.

Based on the background and problem formulation that has been described, the objectives compiled in this research is to describe the supply chain system of white pepper muntok and analyze the performance of muntok white pepper supply chain in the province of Bangka Belitung Islands.

\section{METHODS OF RESEARCH}

This research was conducted in Bangka Belitung Islands Province, by choosing South Bangka Regency as the location of sample selection of respondents (farmers as producers). Site selection is purposive with consideration that South Bangka Regency is the main production area and main supplier of white pepper for both domestic consumption and export requirement, so it is considered to provide supply chain information and enable data collection as needed. This research was conducted from July 2017 until September 2017.

Determination of sample of farmer respondents is done by purposive sampling that is white pepper farmer that completely consist of cultivation and sale of white pepper, counted 25 farmers. Furthermore, the sample determination of respondents of supply chain is done by snowball sampling method, that is by tracing the flow of white pepper supply chain according to the research boundary, the total of the respondent of merchant in this research is 6 people. Details of white pepper supply chain traders and collecting traders at 5 districts / sub-districts, and exporting companies 1 . The total sample size of the sample is 31 respondents.

Methods Data analysis used descriptive analysis method quantitative and qualitative. Qualitative descriptive is used to describe a white pepper supply chain system with a supply chain development method that follows the supply chain networking (SCN) of Lambert and Cooper and then modified by Van der Vorst (Vorst 2008). Each section within the framework is analyzed descriptively in the form of five SCN frameworks: supply chain objectives, supply chain structure, supply chain management, supply chain resources, supply chain business processes. Then quantitative descriptive is used to analyze the performance of supply chain that is seen from marketing margin and farmer's share.

\section{RESULTS AND DISCUSSION}

The agricultural sector is the leading sector and the priority of regional development in South Bangka Regency. The main commodities of its plantation subsector are white pepper, rubber, palm oil and coconut. Pepper is the pepper producing district with the highest total production compared to other districts in the province of bangka belitung.According to 
Bangka Pos, 2017: South Bangka Regency is the center of producing two thirds of pepper in the province of Bangka Belitung, the majority of the people's gardens involving approximately 57,000 farm families.

Information on the level of education that has been passed by pepper farmers in South Bangka Regency and the perpetrators of marketing in this study refers to the level of formal education, namely schooling education starting from primary school to college (PT). Detailed information on the level of education of respondents can be seen in Table 2.

Table 2 - Distribution of Respondents Education Level

\begin{tabular}{ccccc}
\hline Respondents & \multicolumn{4}{c}{ Education Level } \\
\cline { 2 - 4 } & SD & SMP & SMA & PT \\
\hline Pepper Farmer & 14 & 6 & 5 \\
Village Collectors & 3 & 2 & & \\
District Collector Traders & & 2 & 1 \\
Great Traders (export) & & & \\
\hline
\end{tabular}

Source: Prepare primary data 2017.

Based on the information in Table 2, Respondents generally obtain education from elementary school (SD) to college level. Regional, social, and economic factors of each respondent are the main reasons for the limitations in obtaining higher levels of education. Factors of limitations in science can affect the marketing system applied by farmers and gatherers.

According to BPS (2016), productive age ranges between 15-65 years, while non productive age is 1-14 years and above 65 years. Details of information on the age level of pepper farmers and their marketing actors are shown in Table 3.

Table 3 - Distribution of Age Level of Respondents

\begin{tabular}{ccc}
\hline Respondents & $\begin{array}{c}\text { Productive age } \\
12-65 \text { years old } \\
\text { (people) }\end{array}$ & $\begin{array}{c}\text { Non-productive age } \\
>65 \text { Years } \\
\text { (people) }\end{array}$ \\
Pepper Farmer & 25 & - \\
Village Collectors & 3 & - \\
District Collector Traders & 2 & - \\
Great Traders (export) & 1 & - \\
\hline
\end{tabular}

Source: Prepare primary data 2017.

The respondents' experience in conducting pepper farming activities is divided into three categories: first one to 10 years, second category 11 to 20 and third category over 20 years. The longer time farmers and middlemen spend in farming, the more they will know and experience in cultivation to harvest the white pepper.

Based on Table 4 it can be seen that the farmers have experience of white pepper farming about 1 - 10 years ie 13 farmers with percentage of $41.93 \%$ while the fewest farmers with experience of 11-20 years. And Experience owned merchant traders is the time range of 11-20 years. Havelock (1969) argues that one's experience affects his tendency to require and be ready for new knowledge.

Table 4 - Distribution of Respondent Experience in White Pepper Farming

\begin{tabular}{cccccc}
\hline \multirow{2}{*}{ No } & \multirow{2}{*}{ Length of farming (year) } & \multicolumn{4}{c}{ Respondents } \\
\cline { 3 - 5 } & $1-10$ & Farmer & Persentase & Collectors & $\%$ \\
\hline 1 & $11-20$ & 13 & 41,93 & \\
2 & $>20$ & 6 & 19,35 & 5 & 16,13 \\
3 & 7 & 22,58 & & \\
\hline
\end{tabular}

Source: Prepared primary data, 2017. 


\section{White Pepper Supply Chain System:}

1. Target Supply Chain:

White pepper market targets are generally intended for export markets. This is due to the productivity of the high pepper white pepper culture. Therefore, this supply chain has been marketing products to several countries abroad, such as countries in the Continent. There is a Grade in white pepper that is marketed so that the sorting process is complicated. The sorting process performed separates all other forms of white pepper themselves, such as: leaves, stems from whole grains of white pepper. This activity is done by all members of the supply chain.

2. Supply Chain Structure: Figure 2.

The structure of white pepper supply chain in South Bangka Regency is presented in

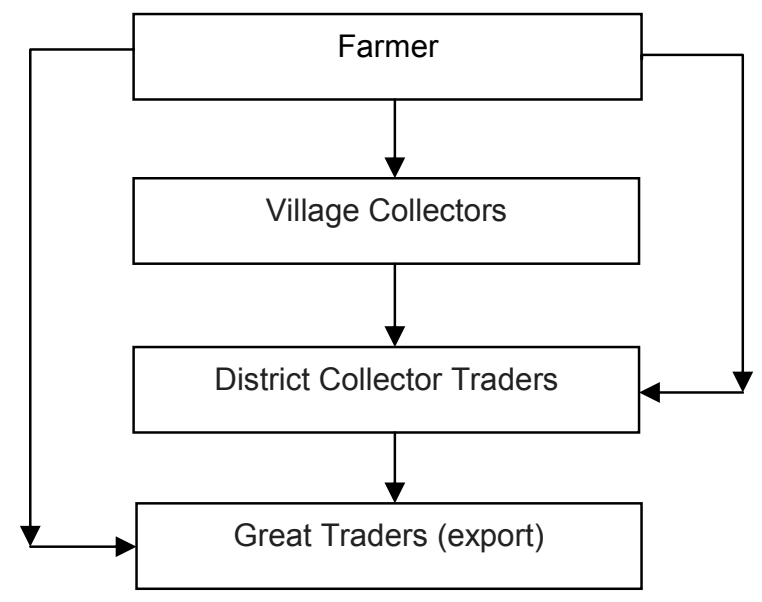

Figure 2 - White pepper supply chain structure in South Bangka Regency

Channel I: Farmers sell to village-level collectors, then to district-level merchant collectors which then district-level traders sell to exporters

Channel II: Farmers sell to district-level merchant collectors which then immediately sell to exporters

Channel III: Farmers sell directly to exporters

Based on interviews with AELI (Indonesian Pepper Export Association) almost 90 percent of Bangka Belitung pepper is exported to European, American and Asian countries. While 10 percent white pepper Bangka Belitung traded between regions (islands) or domestic.

1. Supply Chain Management:

Chain management is a joint planning, organizing, implementing and monitoring process undertaken in the white pepper supply chain. In this case, white pepper supply chain management is a contractual agreement and the transaction system has not gone well.

2. Supply Chain Resources:

The resources of each member of the supply chain play a role in the development of all members of the supply chain. In this case Resources that can be studied ie physical resources and capital is in accordance with the needs of the supply chain because these resources serve to improve the performance of the whole supply chain.

3. Supply Chain Business Process:

The business process chain reflects the processes that occur along the white pepper supply chain. The business process of white pepper supply chain is not smoothly between farmers to exporters because it is seen from the pattern of distribution.

The performance of the pepper supply chain in Bangka Belitung Province will be measured through marketing efficiency with marketing margin and farmer's share tools. 
Table 5 - Margin and Function of Supply Chain Marketing of Marketing Institutions

\begin{tabular}{|c|c|c|c|c|c|c|}
\hline \multirow{2}{*}{$\begin{array}{l}\text { Marketing } \\
\text { Institution }\end{array}$} & \multirow{2}{*}{$\begin{array}{l}\text { Channel } \\
1(\mathrm{Rp} / \mathrm{kg})\end{array}$} & \multirow{2}{*}{$\begin{array}{l}\text { Channel } \\
2(\mathrm{Rp} / \mathrm{kg})\end{array}$} & \multirow{2}{*}{$\begin{array}{l}\text { Channel } \\
3(\mathrm{Rp} / \mathrm{kg})\end{array}$} & \multicolumn{3}{|c|}{ Marketing Function } \\
\hline & & & & $\begin{array}{l}\text { Exchange } \\
\text { Function }\end{array}$ & $\begin{array}{l}\text { Physical } \\
\text { Function }\end{array}$ & Facility Function \\
\hline $\begin{array}{l}\text { Pepper } \\
\text { farmers }\end{array}$ & & & & \multirow[t]{2}{*}{ Sales function } & \multirow{2}{*}{$\begin{array}{l}\text { Function } \\
\text { storage }\end{array}$} & \multirow{2}{*}{$\begin{array}{l}\text { Function finance,Risk } \\
\text { containment function }\end{array}$} \\
\hline Selling price & 66.000 & 70.000 & 78.000 & & & \\
\hline $\begin{array}{c}\text { Village } \\
\text { Collectors }\end{array}$ & & & & \multirow{4}{*}{$\begin{array}{l}\text { Purchase } \\
\text { function, sales } \\
\text { function, } \\
\text { collection } \\
\text { function }\end{array}$} & \multirow{4}{*}{$\begin{array}{l}\text { Function } \\
\text { storage , } \\
\text { transport } \\
\text { function }\end{array}$} & \multirow{4}{*}{$\begin{array}{l}\text { Standardization } \\
\text { function, Function } \\
\text { finance, Risk } \\
\text { containment function }\end{array}$} \\
\hline $\begin{array}{l}\text { Purchase } \\
\text { price }\end{array}$ & 66.000 & & & & & \\
\hline Selling price & 70.000 & & & & & \\
\hline Margin & 3.000 & & & & & \\
\hline District & & & & \multirow{5}{*}{$\begin{array}{l}\text { Purchase } \\
\text { function, sales } \\
\text { function, } \\
\text { collection } \\
\text { function }\end{array}$} & \multirow{5}{*}{$\begin{array}{l}\text { Function } \\
\text { storage, } \\
\text { transport } \\
\text { function }\end{array}$} & \multirow{5}{*}{$\begin{array}{l}\text { Standardization } \\
\text { function, Function } \\
\text { finance, Risk } \\
\text { containment function }\end{array}$} \\
\hline $\begin{array}{l}\text { Collector } \\
\text { Traders }\end{array}$ & & & & & & \\
\hline $\begin{array}{c}\text { Purchase } \\
\text { price }\end{array}$ & 70.000 & 70.000 & & & & \\
\hline Selling price & 78.000 & 78.000 & & & & \\
\hline Margin & 8.000 & 8.000 & & & & \\
\hline Export & & & & \multirow{4}{*}{$\begin{array}{c}\text { Purchase } \\
\text { function, sales } \\
\text { function, } \\
\text { collection } \\
\text { function }\end{array}$} & \multirow{4}{*}{$\begin{array}{l}\text { Function } \\
\text { storage }\end{array}$} & \multirow{4}{*}{$\begin{array}{c}\text { Standardization } \\
\text { function, Function } \\
\text { finance, Risk } \\
\text { containment function } \\
\text { The function of market } \\
\text { intelligence }\end{array}$} \\
\hline $\begin{array}{l}\text { Purchase } \\
\text { price }\end{array}$ & 78.000 & 78.000 & 78.000 & & & \\
\hline Selling price & 117.000 & 117.000 & 117.000 & & & \\
\hline Marjin & 39.000 & 39.000 & 39.000 & & & \\
\hline $\begin{array}{c}\text { Total } \\
\text { Margin }\end{array}$ & 50.000 & 47.000 & 39.000 & & & \\
\hline
\end{tabular}

Source: Prepared primary data, 2017.

Farmer's share is a percentage of the selling price of pepper received by farmers against the selling price of pepper paid by the end consumer. Pepper selling price at the farm level of Rp. 66,000 per kg while the selling price of pepper paid by end consumers varies in each channel:

Farmer's share chain of supply channels $1=56,7 \%$;

Farmer's share chain of supply channels $2=59,8 \%$;

Farmer's share chain of supply channels $3=66,7 \%$.

The value of farmer's share in the supply chain of pepper on channel 3 is 66.7 percent. The value of farmer's share is quite large as there are only two marketing institutions in this channel. From that value, it is evident that exporters want to make the farmers prosperous according to their business objectives. Judging from the overall value of farmer's share, there is a considerable share of farmer's share. This shows that the pepper supply chain is quite efficient. It is also supported from the results of marketing margin analysis. A large margin of marketing value leads to a small share of the farmer's share and makes the marketing of the pepper supply chain inefficient so as to make the price offered by the pepper supply chain not competitive yet.

\section{CONCLUSION}

Supply chain system muntok white pepper in Bangka Belitung Islands Province has a clear supply chain objective. Supply chain structure consists of white pepper farmers, villagelevel collectors, district and city collector traders and exporters, Implementation of chain management the supply has not gone well because the transaction system specified by the exporter is detrimental to the white pepper farmers themselves. The resources owned by the white pepper supply chain are in accordance with the supply chain requirements. The business process in the white pepper supply chain is poorly run due to the lack of financial and information flow smoothly between exporters to farmers.

The performance of the pepper supply chain is quite efficient overall as collecting merchants do not take too much profit in every marketing channel, visible from the margin 
difference is still rational considering each marketing institution performs marketing functions. Farmer's share value obtained by farmers is $66.7 \%$. This indicates that the pepper supply chain is quite efficient on channel 3.

\section{REFERENCES}

1. Anatan L, Ellitan L. 2008. Supply Chain Management Theory and Applications. Bandung: CV. Alfabeta.

2. Aryanthi D. 2011. Analysis of Supply Chain Management of Horticulture Agroindustry (Case Study of Fruit of Guava Lipisari in B2PTTG LIPI Subang) [thesis]. Bogor: Faculty of Economics and Management, Bogor Agricultural University.

3. Chopra S, Meindl P. 2004. Supply Chain Management: Strategy, Planning, and Operation. USA: Pearson Prentice Hall.

4. Helena. 2010. Analysis of Procurement System and Control of Traditional Herbal Supplies Raw Material at PT. X Bogor [thesis]. Bogor: Faculty of Agriculture, Bogor Agricultural University.

5. Indrajit RE and Djokopranoto R. 2006. Supply Chain Management Concepts New Way of Looking at Supply Chain Supply Chain. Jakarta: Grasindo.

6. [IPC] International Pepper Community, 2015. Pepper Statistical Yearbook 2010-2014. Jakarta (ID): International Pepper Community.

7. Kohls RL and Uhl JN. 2002. Marketing of Agricultural Products. Purdue University. New York: Mc Millan Publishing Company.

8. LPPM University of Bangka Belitung. 2015. Study of pepper financing and commodity models in the Province of Babel Islands: Bank Indonesia.

9. Panggabean, David. 2009. Logistics Analysis Using Supply Chain Management (SCM) Concepts in PT. Perkebunan Nusantara III Gunung Para [thesis]. Medan: Faculty of Engineering, University of North Sumatra.

10. Riwanti W. 2011. Organic Broccoli Supply Chain Management (Case Study of Agro Sustainable in Cibogo, Bogor Regency, West Java) [thesis]. Bogor: Faculty of Economics and Management, Bogor Agricultural University.

11. Van der Vorst, JGAJ. 2006. Performance Measurement in Agri-Food Supply Chain Networks. Netherland: Logistics and Operations Research Group, Wageningen University.

12. Wicaksono, DA. 2010. Analysis of Supply Chain Strategy of Vaname Shrimp (Case Study of Plasma Farmer of Pandu Karawang, Bogor Regency, West Java [thesis] Bogor: Faculty of Economics and Management. Bogor. 